\title{
Chemical profiling of a polyherbal formulation by tandem mass spectroscopic analysis with multiple ionization techniques
}

\author{
Sulaiman C. T. ${ }^{*}$ (D), Ramesh P. R. ${ }^{2}$, Mahesh K. ${ }^{2}$, Madhu K. M. ${ }^{3}$, Anandan E. M. ${ }^{4}$, Praveen M. ${ }^{3}$ and Indira Balachandran ${ }^{1}$
}

\begin{abstract}
Background: Gugguluthiktham Kashayam (GTK) is the decoction form of Panchatikta Guggulu Ghrita, a classical Ayurvedic formulation used for treating various diseases like skin disorders, ulcers, sinus, asthma, cardiac diseases, arthritis, and cancer.

Results: Tandem mass spectroscopic analysis of GTK was carried out by different ionization techniques such as electro spray ionization (ESI) and atmospheric pressure chemical ionization (APCI) in both positive and negative modes using Quadrupole Time-of-Flight (Q-TOF) mass spectroscopy. Data processing of molecular ions obtained by $\mathrm{ESI}$ and $\mathrm{APCl}$ mass fragmentation led to the identification of several phytoconstituents belonging to various classes of compounds such as phenolics, flavonoids, and coumarins.

Conclusion: The study concluded that GTK contains variety of phytochemicals with numerous biological properties that might be responsible for its various therapeutic effects.
\end{abstract}

Keywords: Gugguluthiktham Kashayam, Herbal formulation, ESI, APCI, LCMS

\section{Background}

Indian traditional medicines such as Ayurveda, Unani, and Siddha, have been practiced by billions of people for many centuries. Ayurvedic formulations contain multiple botanicals as ingredient materials some may be made with minerals, metals, and ingredients of animal origin, and each of these comprises a number of chemical compounds that may give the anticipated activity in combination. Polyherbal formulations show high effectiveness due to the presence of active phytochemicals that are further potentiated with synergetic interaction of active components of ingredient plants. GTK is the decoction form of Panchatikta Guggulu Ghrita, a classical Ayurvedic formulation used for treating various disease conditions including skin disorders,

\footnotetext{
*Correspondence: sulaimanct@aryavaidyasala.com; slmnct@gmail.com ${ }^{1}$ Centre for Medicinal Plants Research, Arya Vaidya Sala, Kottakkal, Kerala, India

Full list of author information is available at the end of the article
}

ulcers, sinus, asthma, cardiac diseases, arthritis, and cancer [1-3].

Liquid chromatography-tandem mass spectrometry has become the best method for separation, identification, and characterization of active constituents of herbal products and had a significant impact on drug development over the past decade. Continual improvements in LC/MS interface technologies combined with powerful features for structure analysis, qualitative and quantitative, have resulted in a widened scope of application, especially natural products. The advancement of multiple ionization techniques for the characterization of unknown samples has been reported earlier $[4,5]$.

Although research on Ayurveda has become a popular trend now, only a very small percentage of Ayurvedic medicines have been investigated targeting on their chemical components and biological activities. There are still a huge number of Ayurvedic preparations that are not investigated chemically. Most of the Ayurvedic classical 


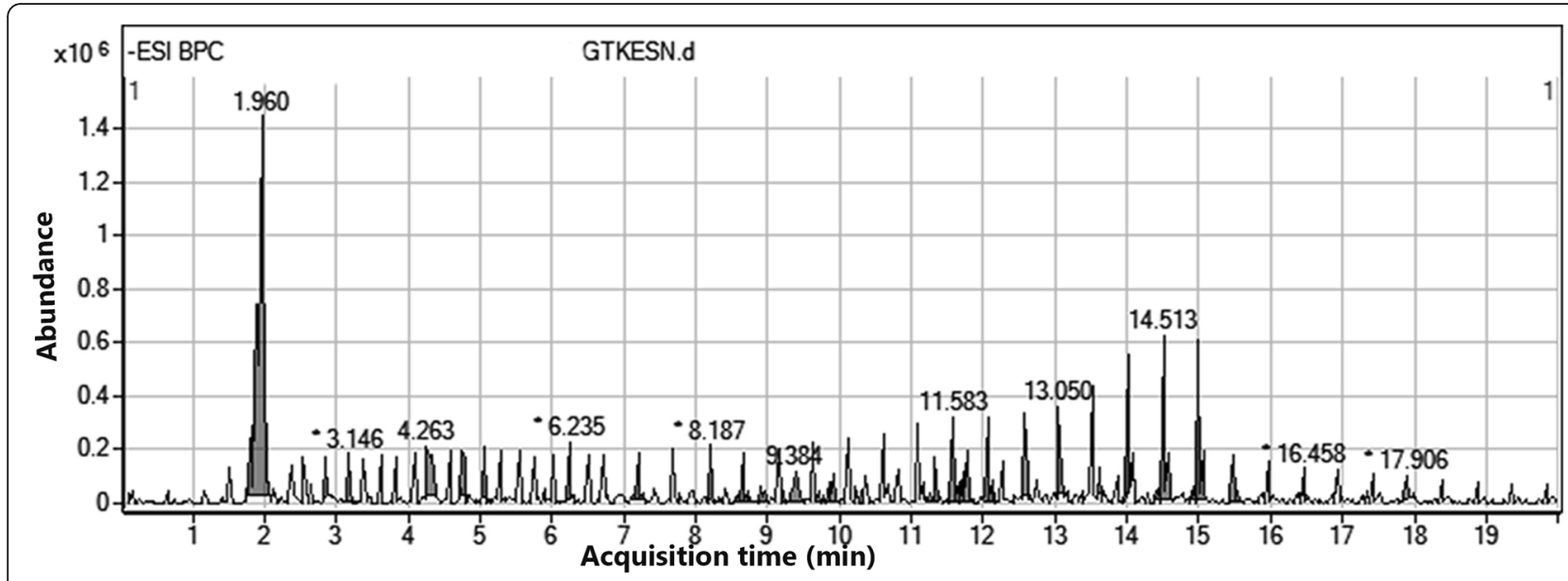

Fig. 1 ESI-MS-base peak chromatogram of GTK in negative ionization

Table 1 ESI-LC-MS/MS analysis of GTK

\begin{tabular}{|c|c|c|c|c|c|c|}
\hline SI no. & $m / z$ & MS/MS & Tentative identification & Type of compound & Molecular formula & Ionization mode \\
\hline 1 & 191.0568 & 173.10 & Quinic acid & Phenolics & $\mathrm{C}_{7} \mathrm{H}_{11} \mathrm{O}_{6}$ & Negative \\
\hline 2 & 197.1452 & $179.02,135.12$ & Syringic acid & Phenolics & $\mathrm{C}_{9} \mathrm{H}_{10} \mathrm{O}_{5}$ & Negative \\
\hline 3 & 153.0260 & 109.24 & Protocatechuic acid & Phenolics & $\mathrm{C}_{7} \mathrm{H}_{6} \mathrm{O}_{4}$ & Negative \\
\hline 4 & 153.0256 & 109.03 & 2,5-Dihydroxybenzoic acid & Phenolics & $\mathrm{C}_{7} \mathrm{H}_{6} \mathrm{O}_{4}$ & Negative \\
\hline 5 & 169.015 & 125.02 & Gallic acid & Phenolics & $\mathrm{C}_{7} \mathrm{H}_{6} \mathrm{O}_{5}$ & Negative \\
\hline 6 & 133.0179 & 115.23 & Malic acid & Phenolics & $\mathrm{C}_{4} \mathrm{H}_{6} \mathrm{O}_{5}$ & Negative \\
\hline 7 & 305.0386 & 225.02 & Gallo catechin & Catechin & $\mathrm{C}_{15} \mathrm{H}_{14} \mathrm{O}_{7}$ & Negative \\
\hline 8 & 343.2245 & 299.25 & Anacardic acid (15:2) & Phenolics & $\mathrm{C}_{22} \mathrm{H}_{32} \mathrm{O}_{3}$ & Negative \\
\hline 9 & 341.2087 & 297.24 & Anacardic acid (15:3) & Phenolics & $\mathrm{C}_{22} \mathrm{H}_{30} \mathrm{O}_{3}$ & Negative \\
\hline 10 & 345.2314 & 301.26 & Anacardic acid (15:1) & Phenolics & $\mathrm{C}_{22} \mathrm{H}_{34} \mathrm{O}_{3}$ & Negative \\
\hline 11 & 353.1289 & $191.05,179.12$ & Caffeoylquinic acid & Phenolics & $\mathrm{C}_{16} \mathrm{H}_{18} \mathrm{O}_{9}$ & Negative \\
\hline 12 & 355.023 & $337.02,249.05,116.95$ & Chebulic acid & Phenolics & $\mathrm{C}_{14} \mathrm{H}_{12} \mathrm{O}_{11}$ & Negative \\
\hline 13 & 463.0288 & 301.04 & Quercetin hexoside & Flavonoid & $\mathrm{C}_{21} \mathrm{H}_{20} \mathrm{O}_{12}$ & Negative \\
\hline 14 & 289.0068 & 245.01 & Catechin & Catechin & $\mathrm{C}_{15} \mathrm{H}_{14} \mathrm{O}_{6}$ & Negative \\
\hline 15 & 297.154 & 183.01 & Cardanol & Phenolics & $\mathrm{C}_{22} \mathrm{H}_{30} \mathrm{O}$ & Negative \\
\hline 16 & 173.0491 & $155.03,137.02$ & Shikimic acid & Phenolics & $\mathrm{C}_{7} \mathrm{H}_{10} \mathrm{O}_{5}$ & Negative \\
\hline 17 & 179.0777 & $162,135.08$ & Caffeic acid & Phenolics & $\mathrm{C}_{9} \mathrm{H}_{8} \mathrm{O}_{4}$ & Negative \\
\hline 18 & 237.0538 & 193.06 & 6-Hydroxy flavone & Flavonoid & $\mathrm{C}_{15} \mathrm{H}_{10} \mathrm{O}_{3}$ & Negative \\
\hline 19 & 163.0499 & 119.05 & 2-Coumaric acid & Phenolics & $\mathrm{C}_{9} \mathrm{H}_{8} \mathrm{O}_{3}$ & Negative \\
\hline 20 & 193.0913 & 149.10 & Ferulic acid & Phenolics & $\mathrm{C}_{10} \mathrm{H}_{10} \mathrm{O}_{4}$ & Negative \\
\hline 21 & 447.0657 & 300.16 & Quercetin -3-rhamnoside & Flavonoid & $\mathrm{C}_{21} \mathrm{H}_{20} \mathrm{O}_{11}$ & Negative \\
\hline 22 & 371.037 & $353.02,191.02$ & 2-O-caffeoylglucaric acid & Phenolics & $\mathrm{C}_{15} \mathrm{H}_{16} \mathrm{O}_{11}$ & Negative \\
\hline 23 & 477.0594 & 301.14 & Quercetin-3-glucuronide & Flavonoid & $\mathrm{C}_{21} \mathrm{H}_{17} \mathrm{O}_{13}$ & Negative \\
\hline 24 & 255.245 & 209.12 & 2',6-Dihydroxyflavanone & Flavonoid & $\mathrm{C}_{15} \mathrm{H}_{12} \mathrm{O}_{4}$ & Negative \\
\hline 25 & 610.1259 & 464,302 & Rutin & Flavonoid & $\mathrm{C}_{27} \mathrm{H}_{30} \mathrm{O}_{16}$ & Positive \\
\hline 26 & 757.718 & 301.14 & Quercetin-3-rhamnosyl glucoside & Flavonoid & $\mathrm{C}_{33} \mathrm{H}_{40} \mathrm{O}_{20}$ & Positive \\
\hline 27 & 449.427 & 287.26 & Kaempferol 7-O-glucoside & Flavonoid & $\mathrm{C}_{21} \mathrm{H}_{42} \mathrm{O}_{11}$ & Positive \\
\hline 28 & 271.257 & $253.36,225.17$ & Apigenin & Flavonoid & $\mathrm{C}_{15} \mathrm{H}_{10} \mathrm{O}_{5}$ & Positive \\
\hline
\end{tabular}




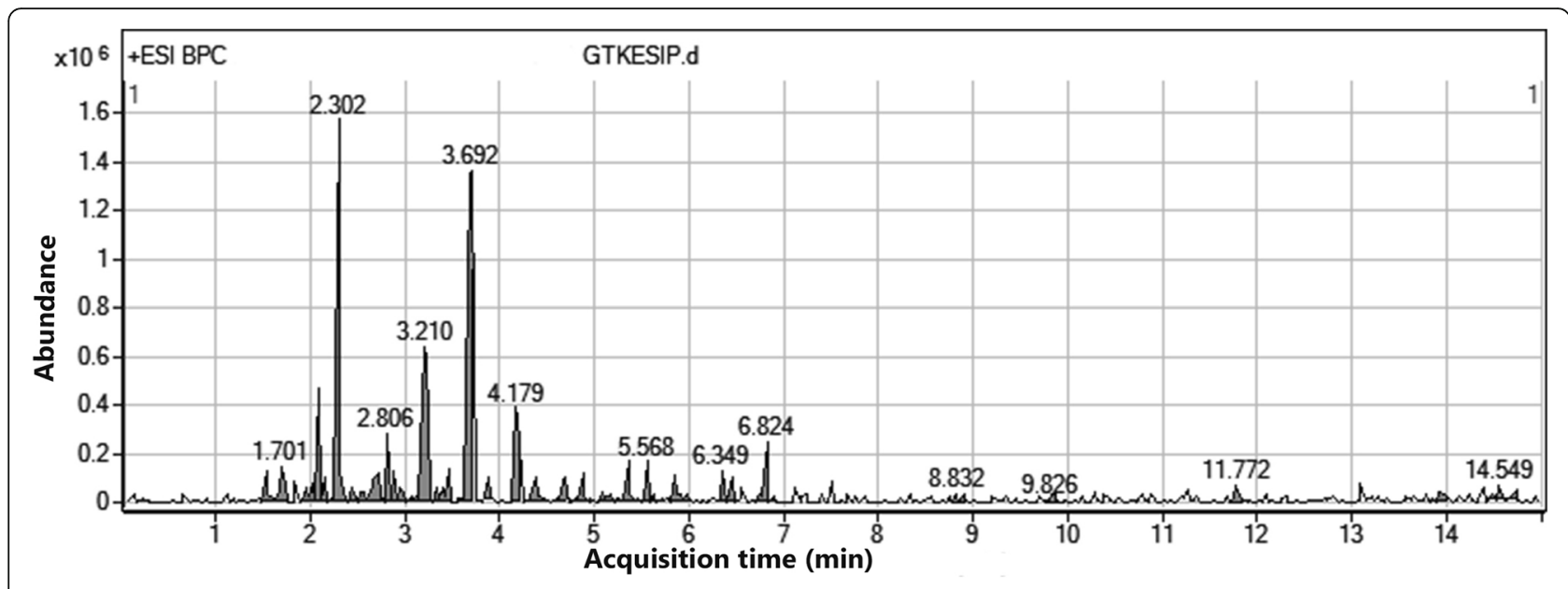

Fig. 2 ESI-MS-base peak chromatogram of GTK in positive ionization

formulations are Polyherbal preparations and their unique processing methods turn the ingredients into very complex mixtures, from which the separation and identification of chemical components is very difficult. It will be very imperative in the future to gain a better understanding of the chemical basis of these medicines. The present study is focused on the chemical analysis of an Ayurvedic formulation using tandem mass spectroscopic investigation with multiple ionization techniques.

\section{Methods}

\section{Preparation of GTK}

GTK was prepared by the Product Development Department of Arya Vaidya Sala, Kottakkal, Kerala, India, as per the method of Ayurvedic Formulary of India [1] and was dried into powder form using vacuum evaporator. Ten grams of this was dissolved in LC/MS grade methanol and kept under refrigerator until LC/MS analysis.
Instruments and general chromatographic conditions LC-MS/MS experiments were performed on Agilent 6520 accurate mass Q-TOF-MS coupled with Agilent LC 1200 equipped with Extend-C18 column of $1.8 \mu \mathrm{m}, 2.1 \times 50$ $\mathrm{mm}$. The MS analysis was performed using ESI and APCI ionization techniques in positive and negative mode. Maas spectral data analysis was done by Agilent molecular ion extraction algorithm. The general conditions for mass spectrometry were drying gas (nitrogen) flow $8 \mathrm{~L} / \mathrm{min}$; nebulizer pressure 40 psig; drying gas temperature $300^{\circ} \mathrm{C}$; capillary voltage $3000 \mathrm{~V}$; fragmentor volt $125 \mathrm{~V}$; Oct RF Vpp $750 \mathrm{~V}$. The injection volume was $20 \mu \mathrm{l}$.

\section{Optimization of LC/MS method}

After several trail injections, the best mobile phase was fixed as gradient of acidified methanol (A) and water (B) system for ESI ionization mode. Gradient elution was performed at a constant flow rate of $0.9 \mathrm{ml} / \mathrm{min}$, with an

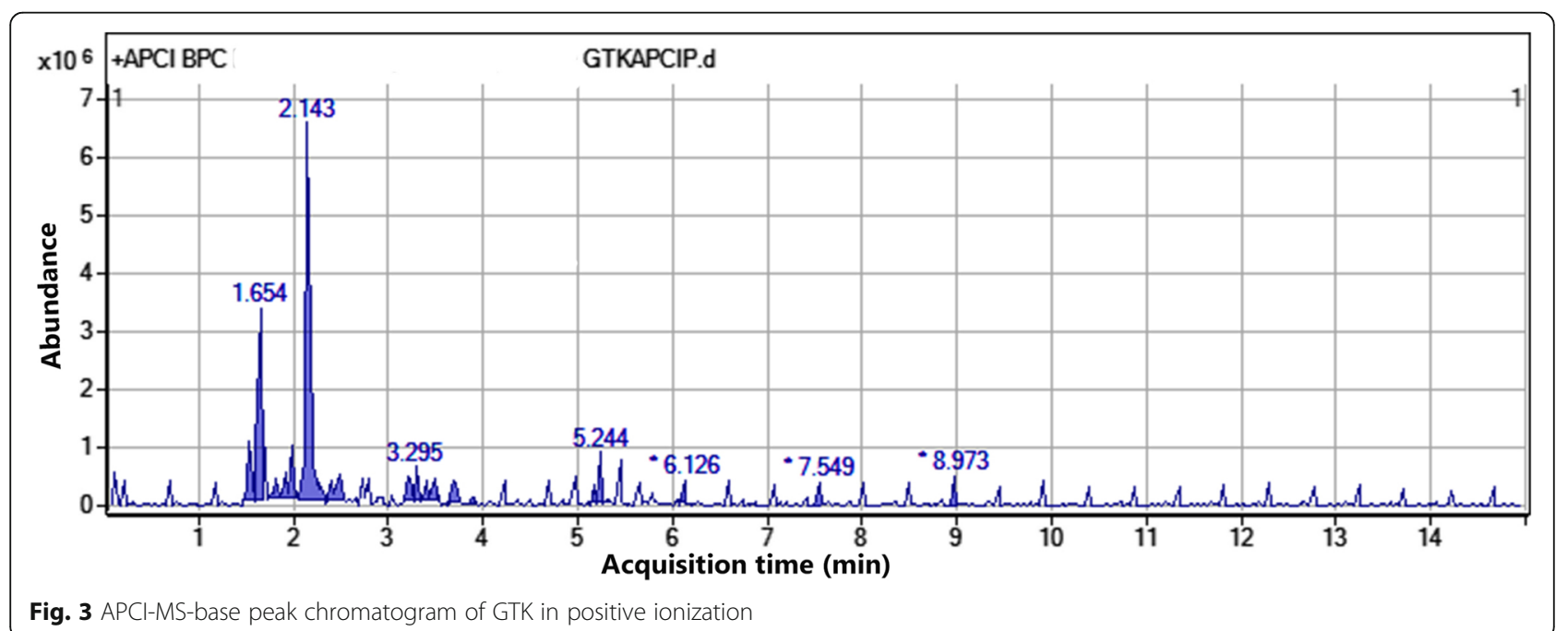

Fig. 3 APCI-MS-base peak chromatogram of GTK in positive ionization 
Table 2 APCI-LC-MS/MS analysis of GTK

\begin{tabular}{lllllll}
\hline SI no. & $\mathrm{m} / \mathrm{z}$ & MS/MS & Tentative identification & Type of compound & Molecular formula & lonization mode \\
\hline 1 & 193.0566 & 133.03 & 7-Hydroxy-6-methoxy coumarin & Coumarin & $\mathrm{C}_{10} \mathrm{H}_{8} \mathrm{O}_{4}$ & Positive \\
2 & 177.1412 & 77.23 & 4-Methylumbelliferone & Coumarin & $\mathrm{C}_{10} \mathrm{H}_{8} \mathrm{O}_{3}$ & Positive \\
3 & 217.0593 & 202.02 & 5-Methoxy-6,7-furanocoumarin & Coumarin & $\mathrm{C}_{12} \mathrm{H}_{8} \mathrm{O}_{4}$ & Positive \\
4 & 163.0441 & 107.05 & 7-Hydroxycoumarin & Coumarin & $\mathrm{C}_{9} \mathrm{H}_{6} \mathrm{O}_{3}$ & Positive \\
5 & 219.2102 & 115.24 & 8-Acetyl-7-methoxycoumarin & Coumarin & $\mathrm{C}_{12} \mathrm{H}_{10} \mathrm{O}_{4}$ & Positive \\
6 & 163.0396 & 144.12 & p-coumaric acid & Phenolics & $\mathrm{C}_{9} \mathrm{H}_{8} \mathrm{O}_{3}$ & Negative \\
7 & 187.210 & 167.08 & Azelaic acid & Carboxylic acid & $\mathrm{C}_{9} \mathrm{H}_{16} \mathrm{O}_{4}$ & Negative \\
8 & 299.253 & 179.16 & Diosmetin & Flavonoid & $\mathrm{C}_{16} \mathrm{H}_{12} \mathrm{O}_{6}$ & Negative \\
9 & 455.3528 & 438.20 & Betulinic acid & Phenolics & $\mathrm{C}_{30} \mathrm{H}_{48} \mathrm{O}_{3}$ & Negative \\
10 & 431.0918 & 270.25 & Apigenin 7-O-glucoside & Flavonoid & $\mathrm{C}_{21} \mathrm{H}_{20} \mathrm{O}_{10}$ & Negative \\
\hline
\end{tabular}

increase in the volume of $\mathrm{B} \%$; $2-20 \%, 4-30 \%, 8-40 \%, 10-$ $50 \%, 12-40 \%, 15-50 \%$. The mass fragmentation was performed with varying collision energy $4 \mathrm{~V} / 100 \mathrm{DA}$ with an offset of $6 \mathrm{~V}$. For APCI ionization, the mobile phase was optimized as $0.1 \%$ ammonium format in water (A) and acetonitrile (B) in a gradient elution by changing percentage of A; 2-30\%, 4-40\%, 8-50\%, 10-60\%, 12-50\%, $15-40 \%$. The mass fragmentation was performed with varying collision energy $4 \mathrm{~V} / 100 \mathrm{DA}$ with an offset of 8 V.

\section{Results}

\section{Identification of compounds by ESI ionization}

LC/MS analysis was carried out with ESI ionization in both positive and negative modes. The total ion chromatogram (TIC) was extracted to molecular ions with the Agilent Mass Hunter software. In negative mode, TIC showed 53 molecular ion peaks and based on the abundance 30 ions were further fragmented in auto ms/ $\mathrm{ms}$ analysis with varying collision energy. TIC was extracted to base peak chromatogram (BPC) by Agilent molecular ion extraction algorithm. The consistency of fragments was confirmed by targeted $\mathrm{ms} / \mathrm{ms}$ analysis with fixed collision energy based on the auto $\mathrm{ms} / \mathrm{ms}$ analysis. The ESI-MS fingerprint of GTK in negative mode (Fig. 1, Table 1) presented the ions of $\mathrm{m} / \mathrm{z} 191-$ quinic acid, $\mathrm{m} / \mathrm{z}$ 197.1452-syringic acid, $\mathrm{m} / \mathrm{z}$ 153.0260 - protocatechuic acid, m/z 153.0256 - 2,5-Dihydroxybenzoic acid, $\mathrm{m} / \mathrm{z}$ 169.015-gallic acid, $\mathrm{m} / \mathrm{z}$ 133.0179-malic acid, m/z 305.0386-gallo catechin [6, 7]. Anacardic acids such as anacardic acid (15:1), anacardic acid (15:2), and anacardic acid (15:3) were identified with $\mathrm{m} / \mathrm{z} 345.2314,343.2245$, and 341.2087 respectively $[8,9]$.

The fragmentation patterns of ions with $\mathrm{m} / \mathrm{z} 353.1289$, 355.023, 463.0288, 289.0068, 297.154, 173.0491, and 179.0777 are in consistent with that of caffeoylquinic acid, chebulic acid, quercetin hexoside, catechin, cardanol, shikimic acid, and caffeic acid when compared with that of previous reports [10-12]. Phenolics such as 6hydroxy flavone $(\mathrm{m} / \mathrm{z} 237.0538), 2$-coumaric acid $(\mathrm{m} / \mathrm{z}$ 163.0499), ferulic acid (m/z 193.0913), quercetin-3-

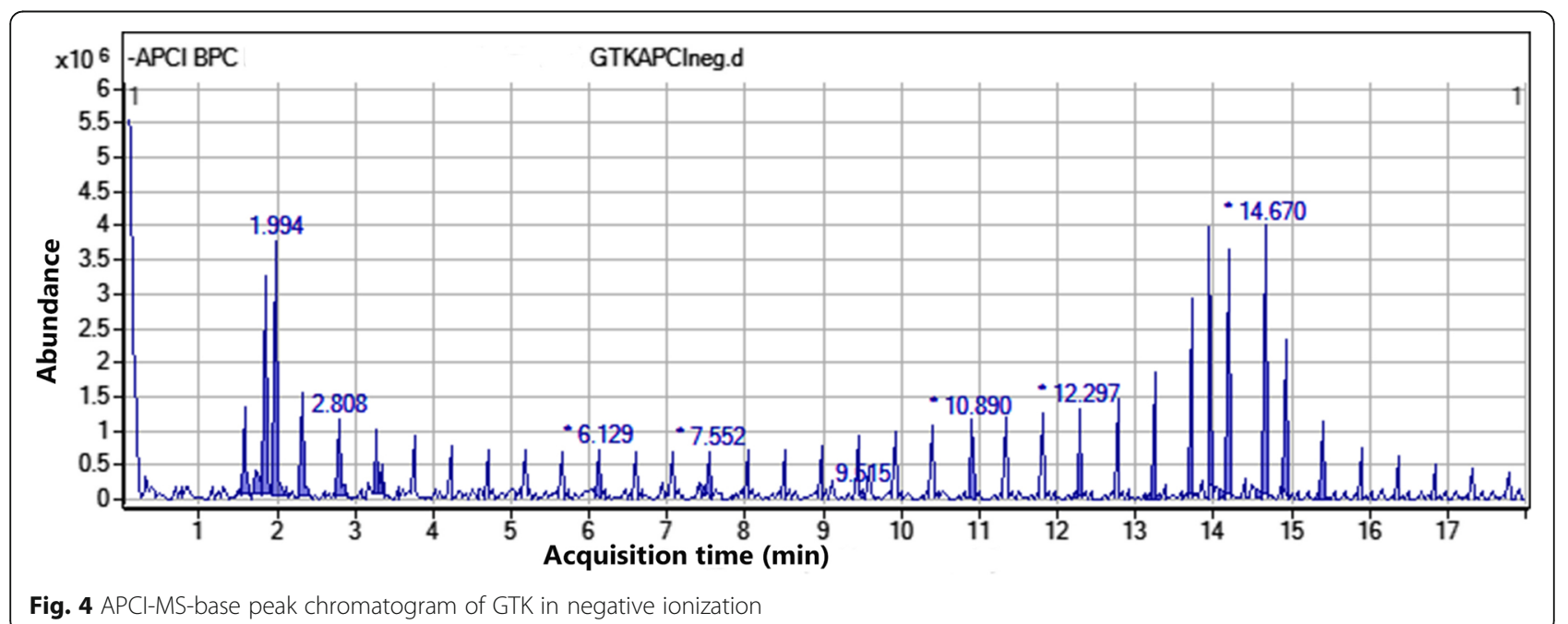

Fig. 4 APCl-MS-base peak chromatogram of GTK in negative ionization 
Table 3 Pharmacological properties of compounds identified from GTK

\begin{tabular}{|c|c|c|c|}
\hline $\begin{array}{ll}\text { Sl } \\
\text { no. }\end{array}$ & $\begin{array}{l}\text { Compounds identified } \\
\text { from GTK }\end{array}$ & Pharmacological properties & Reference \\
\hline 1 & Quinic acid & Anticancer, anti-inflammatory, neuroprotective, antioxidant & [19] \\
\hline 2 & Syringic acid & Anticancer, anti-diabetic, anti-inflammatory, anti-microbial, hepatoprotective & {$[20,21]$} \\
\hline 3 & Protocatechuic acid & Anticancer, anti-diabetic, antiulcer, anti-inflammatory, analgesic, hepatoprotective & {$[22,23]$} \\
\hline 4 & $\begin{array}{l}\text { 2,5-Dihydroxybenzoic } \\
\text { acid }\end{array}$ & Anti-inflammatory, antirheumatic, antioxidant & [24] \\
\hline 5 & Gallic acid & Anticancer, antimicrobial, antioxidant, anti-inflammatory & [25] \\
\hline 6 & Malic acid & Cardioprotective, antioxidant & [26] \\
\hline 7 & Gallo catechin & Anticancer, anti-cholesterol, antioxidant & [27] \\
\hline 8 & Anacardic acid (15:2) & Anticancer, anti-inflammatory, lipoxygenase (LOX-1), xanthine oxidase, tyrosinase & [28] \\
\hline 9 & Anacardic acid (15:3) & Anticancer, anti-inflammatory, lipoxygenase (LOX-1), xanthine oxidase, tyrosinase & [28] \\
\hline 10 & Anacardic acid (15:1) & Anticancer, anti-inflammatory, lipoxygenase (LOX-1), xanthine oxidase, tyrosinase & [28] \\
\hline 11 & Caffeoylquinic acid & Anticancer, anti-inflammatory, lipoxygenase (LOX-1), xanthine oxidase, tyrosinase & [19] \\
\hline 12 & Chebulic acid & Anti-diabetic, antioxidant, anti-angiogenic, anti-inflammatory & [29] \\
\hline 13 & Quercetin hexoside & Aantioxidant, anti-inflammatory & [30] \\
\hline 14 & Catechin & Anticancer, antioxidant, anti-inflammatory & {$[27,31]$} \\
\hline 15 & Cardanol & Anticancer, anti-inflammatory & [28] \\
\hline 16 & Shikimic acid & Antimicrobial & [32] \\
\hline 17 & Caffeic acid & $\begin{array}{l}\text { Anticancer, antibacterial, antiviral activity, antioxidant, anti-inflammatory, anti-atherosclerotic, immunosti- } \\
\text { mulatory, antidiabetic, cardioprotective, antiproliferative, hepatoprotective }\end{array}$ & [33] \\
\hline 18 & 6-Hydroxy flavone & Antioxidant, analgesic & [34] \\
\hline 19 & 2-Coumaric acid & Anticancer, antimicrobial, antioxidant, anti-inflammatory, antiproliferative & [35] \\
\hline 20 & Ferulic acid & Anticancer, antioxidant, anti-inflammatory & [30] \\
\hline 21 & Quercetin-3-rhamnoside & Anticancer, antioxidant, anti-inflammatory, antiviral, cardiovascular, antimicrobial & {$[30,31]$} \\
\hline 22 & 2-O-caffeoylglucaric acid & Antioxidant, anti-inflammatory & [35] \\
\hline 23 & Quercetin-3-glucuronide & Antioxidant, anti-inflammatory & [34] \\
\hline 24 & 2',6-Dihydroxyflavanone & Antioxidant & [34] \\
\hline 25 & Rutin & Anticancer, antioxidant, anti-inflammatory & {$[30,31]$} \\
\hline 26 & $\begin{array}{l}\text { Quercetin-3-rhamnosyl } \\
\text { glucoside }\end{array}$ & Antioxidant, anti-inflammatory & [31] \\
\hline 27 & $\begin{array}{l}\text { Kaempferol 7-O- } \\
\text { glucoside }\end{array}$ & Anticancer, antioxidant, anti-inflammatory & [36] \\
\hline 28 & Apigenin & Anticancer, antioxidant & [37] \\
\hline 29 & $\begin{array}{l}\text { 7-Hydroxy-6-methoxy } \\
\text { coumarin }\end{array}$ & Anticancer & {$[38]$} \\
\hline 30 & 4-Methylumbelliferone & Anticancer, anti-inflammatory, antibacterial, antifungal, antiviral & [39] \\
\hline 31 & $\begin{array}{l}\text { 5-Methoxy-6,7- } \\
\text { furanocoumarin }\end{array}$ & Anti-inflammatory, antibacterial, antifungal, antiviral & [39] \\
\hline 32 & 7-Hydroxycoumarin & Anticancer, anti-inflammatory & [39] \\
\hline 33 & $\begin{array}{l}\text { 8-Acetyl-7- } \\
\text { methoxycoumarin }\end{array}$ & Anticancer, anti-inflammatory & {$[39]$} \\
\hline 34 & p-coumaric acid & Anticancer, antimicrobial, antioxidant, anti-inflammatory & [35] \\
\hline 35 & Azelaic acid & Anticancer, antityrosinase, antibacterial & {$[40,41]$} \\
\hline 36 & Betulinic acid & Anticancer, antioxidant & [42] \\
\hline 37 & $\begin{array}{l}5,7,3^{\prime} \text {-trihydroxy-4'- } \\
\text { methoxyflavone }\end{array}$ & Anticancer & [43] \\
\hline 38 & Apigenin 7-O-glucoside & Anticancer, antioxidant & {$[37]$} \\
\hline
\end{tabular}


rhamnoside ( $\mathrm{m} / \mathrm{z}$ 447.0657), 2-O-caffeoylglucaric acid (m/z 371.037), quercetin-3-glucuronide ( $\mathrm{m} / \mathrm{z} 477.0594)$, and 2',6-dihydroxy flavanone ( $\mathrm{m} / \mathrm{z}$ 255.245) were identified from GTK by comparing their mass fragments with that of reported values [13-16].

The ESI-MS fingerprint in positive mode (Fig. 2, Table 1) presented the ions of $\mathrm{m} / \mathrm{z}$ 610.1259-rutin, $\mathrm{m} / \mathrm{z}$ 757.718-quercetin-3-rhamnosyl glucoside, $\mathrm{m} / \mathrm{z}$ 449.427-kaempferol 7-O-glucoside, and m/z 271.257apigenin. The mass fragmentation patterns of these compounds have been reported previously [10-12].

Most of the compounds identified by ESI ionization mode are polyphenolics in nature. The characterization was carried out using both negative and positive modes; however, better fragments were obtained with negative mode. The use of ESI method as ionization source in the analysis of phenolic compounds has been reported earlier $[11,12,17]$.

\section{Identification of compounds by APCI ionization}

The mass spectroscopic characterization of GTK was further done by APCI ionization method (Fig. 3, Table 2). In positive mode, APCI-MS finger print showed molecular ions with $\mathrm{m} / \mathrm{z}$ 193.0566, 177.1412, 217.0593, 163.0441, and 219.2102 which were identified as 7-hydroxy-6-methoxy coumarin, 4-methylumbelliferone, 5-methoxy-6,7-furanocoumarin, 7-hydroxycoumarin, and 8-Acetyl-7-methoxycoumarin based on the mass fragmentation pattern [18]. In negative ionization mode (Fig. 4, Table 2), compounds such as p-coumaric acid $(\mathrm{m} / \mathrm{z}$ 163.0396), azelaic acid $(\mathrm{m} / \mathrm{z}$ 187.210), 5,7,3' 'trihydroxy-4' -methoxyflavone $\quad(\mathrm{m} / \mathrm{z}$ 299.253), betulinic acid ( $\mathrm{m} / \mathrm{z} 455.3528)$, and apigenin 7-Oglucoside ( $\mathrm{m} / \mathrm{z} 431.0918)$ have been identified by comparing the mass fragmentation pattern of the same with earlier reports [19].

\section{Discussion}

Quadrupole time-of-flight mass spectrometry (QTOFMS) is an excellent technique to analyze chemical constituents of complex herbal preparations due to its accurate mass measurement, high resolution, and ion separation [15]. Quick data processing procedures and molecular ion extraction algorithm tools have been used to process huge raw data generated from multiple ionization mass analyses. These processed data were thereafter used successfully for correlating with their reported biological properties (Table 3). Most of the compounds identified from GTK are reported to possess various pharmacological activities such as antiinflammatory, antioxidant, cardio protective, anticancer, anti-diabetic, and analgesic.

The correlation of the chemical structure of the identified compounds with their previously reported pharmacological activities showed that most of the compounds have anti-inflammatory, antioxidant, and anticancer properties. Indeed, there are many reports of phenolic compounds showing very effective antioxidant, antiinflammatory, and anticancer activities [30, 31].

The metabolomic profiling of GTK depicted the presence of 38 compounds including 19 phenolics, 11 flavonoids, 5 coumarins, 2 catechins, and 1 dicarboxylic acid. These major phytoconstituents are mainly responsible in curing various diseases as they reported to possess numerous biological activities and out of these, 27 compounds are known for their anticancer activity (Fig. 5).

\section{Conclusion}

In this study a novel method has been developed based on tandem mass spectroscopy to identify the major components of a polyherbal formulation. Ayurvedic formulations are gaining great importance as a cure for several

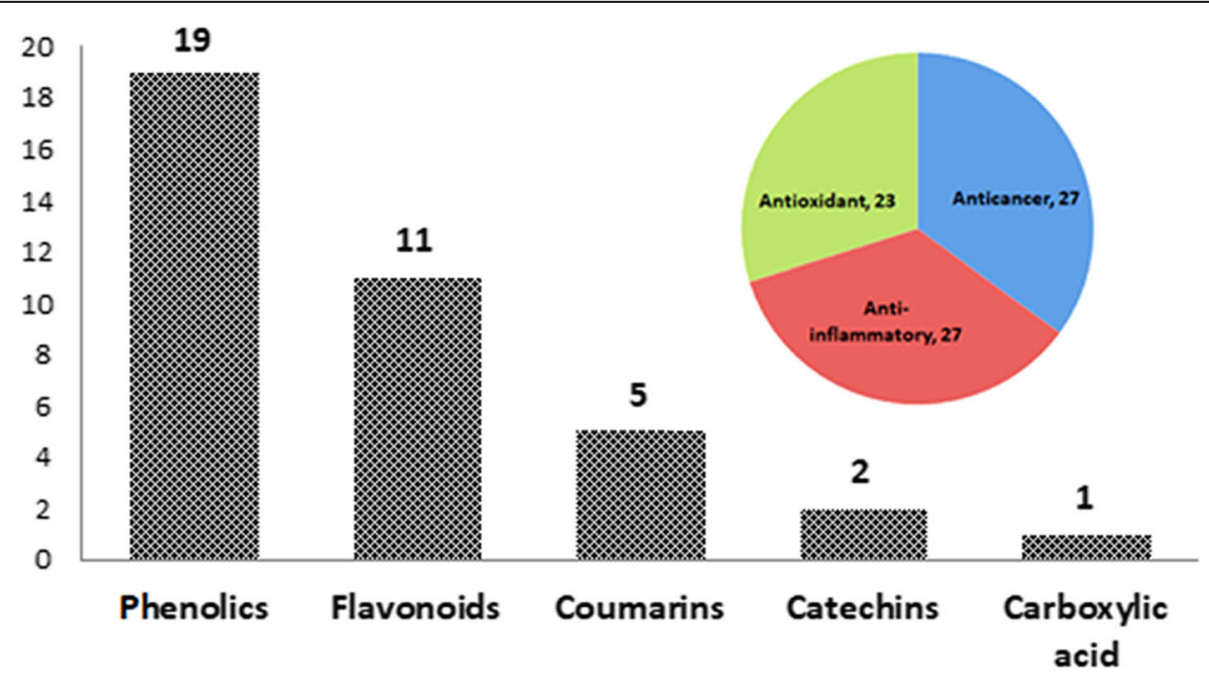

Fig. 5 Major compounds of GTK with their biological activities 
health problems and are getting global attention these days. The ingredient analysis of such herbal preparations is the need of both industry and scientific community to facilitate better understanding about their quality and therapeutic efficacy. The study concluded that GTK, an important Ayurvedic preparation, is a rich source of phytochemicals which are reported mainly for their anticancer, anti-inflammatory, anti-oxidant, and antidiabetic properties.

\section{Abbreviations}

GTK: Gugguluthiktham kashayam; LC-MS/MS: Liquid chromatography-tandem mass spectroscopy; ESI: Electro spray ionization; APCl: Atmospheric pressure chemical ionization; Q-TOF-MS: Quadrupole time-of-flight mass spectrometry; TIC: Total ion chromatogram

\section{Acknowledgements}

The authors are thankful to Dr. P.M Varier, Chief Physician, Arya Vaidya Sala, Kottakkal, and Dr. K. Muraleedharan, Additional Chief Physician, Arya Vaidya Sala, Kottakkal, for their valuable support and encouragement.

\section{Authors' contributions}

SCT: Designed and executed the work, Carried out the LC/MS analysis RPR: Participated in planning and edited the manuscript MK: Provided background data for the design of work MKM: Provided supporting documents for work planning AEM: Prepared the formulation PM: Provided supporting data for the design of work IB: Participated in planning and edited the manuscript All authors have read and approved the manuscript.

\section{Funding}

This work was financially supported by the Navajbhai Ratan Tata Trust, Mumbai, India. The content is solely the responsibility of the authors and does not necessarily represent the official views of the Navajbhai Ratan Tata Trust.

Availability of data and materials

All data and material are available upon request.

\section{Ethics approval and consent to participate}

Not applicable

\section{Consent for publication}

Not applicable

\section{Competing interests}

The authors declare that they have no competing interests.

\section{Author details}

${ }^{1}$ Centre for Medicinal Plants Research, Arya Vaidya Sala, Kottakkal, Kerala, India. ${ }^{2}$ Clinical Research Department, Arya Vaidya Sala, Kottakkal, Kerala, India. ${ }^{3}$ Cancer Clinic, Charitable Hospital, Arya Vaidya Sala, Kottakkal, Kerala, India.

${ }^{4}$ Product Development Department, Arya Vaidya Sala, Kottakkal, Kerala, India.

Received: 31 March 2020 Accepted: 20 July 2020

Published online: 28 July 2020

\section{References}

1. Ayurvedic Formulary of India (2003) Part 1(6):91

2. Bhaishajya Ratnavali, Chapter 54, KUSHT ROG CHIKITSA, Verse: 233 - 236

3. Ashtanga Hridayam, Chikitsa Sthana, Chapter 21, Vatavyadhi Chikitsa Adhyaya, Verse: 58 - 61 .

4. Kailasa SK, Hasan N, Wu HF (2012) Identification of multiply charged proteins and amino acid clusters by liquid nitrogen assisted spray ionization mass spectrometry. Talanta 97:539-549

5. Sulaiman CT, Balachandran I (2015) Chemical profiling of an Indian herbal Formula using liquid chromatography coupled with electro spray ionization mass spectrometry. Spectrosc Lett 48:222-226
6. Sulaiman CT, George S, Thushar KV, Balachandran I (2014) Phenolic characterization of selected Salacia species using LC-ESI-MS/MS analysis Nat. Prod. Res. 28:1021-1024

7. Rodriguez-Medina IC, Segura-Carretero A, Fernandez-Gutierrez A (2009) Use of high-performance liquid chromatography with diode array detection coupled to electrospray-Q-time-of-flight mass spectrometry for the direct characterization of the phenolic fraction in organic commercial juices. J Chromatogr A 1216:4736-4744

8. Filho FO, Alcântra DB, Rodrigues THS, Silva LMA, Silva EO, Zocolo GJ, Brito ES (2018) Development and validation of a reversed phase HPLC method for determination of anacardic acids in cashew (Anacardium occidentale) nut shell liquid. J. Chrom. Sci. 56:300-306

9. Morais SM, Silva KA, Araujo H, Vieira IGP, Alves DR, R. Fontenelle OS, Silva AMS (2017) Anacardic acid constituents from cashew nut shell liquid: NMR characterization and the effect of unsaturation on its biological activities. Pharmaceuticals doi:https://doi.org/10.3390/ph 10010031.

10. Sulaiman CT, Balachandran I (2017) LC/MS characterization of phenolic antioxidants of Brindle berry (Garcinia gummi-gutta (L.) Robson). Nat. Prod. Res 31:1191-1194

11. Sulaiman CT, Nasiya KK, Balachandran I (2016) Isolation and mass spectroscopic characterization of phytochemicals from the bark of Acacia leucophloea (Roxb.) Willd. Spectrosc. Lett 49:391-395

12. Seeram NP, Lee R, Scheuller S, Heber D (2006) Identification of phenolic compounds in strawberries by liquid chromatography electrospray ionization mass spectroscopy. Food Chem. 97:1-11

13. Plazonic A, Bucar F, Males Z, Mornar A, Nigovic B, Kujundzic N (2009) Identification and quantification of flavonoids and phenolic acids in burr parsley (Caucalis platycarpos L.), using high-performance liquid chromatography with diode array detection and electrospray ionization mass spectrometry. Molecules 14:2466-2490

14. Carini M, Facino RM, Aldini G, Calloni M, Colombo L (1998) Characterization of phenolic antioxidants from Mate (llex paraguariensis) by liquid chromatography/mass spectrometry and liquid chromatography/tandem mass spectrometry. Rapid Commun. Mass Spectrom 12:1813-1819

15. Gláucia SV, Marques ASF, Machado MTC, Silva VM, Hubinger MD (2017) Determination of anthocyanins and non-anthocyanin polyphenols by ultraperformance liquid chromatography/electrospray ionization mass spectrometry (UPLC/ESI-MS) in jussara (Euterpe edulis) extracts. J Food Sci Technol 54:2135-2144

16. García LO, Kessler N, Neuweger H, Wendt K, Peinado JMO, Gutiérrez AF, Baessmann C, Pancorbo AC (2018) Unravelling the distribution of secondary metabolites in Olea europaea L.: exhaustive characterization of eight olivetree derived matrices by complementary platforms (LC-ESI/APCI-MS and GC-APCI-MS). Molecules 23:2419. https://doi.org/10.3390/molecules23102419

17. Zeng K, Thompson KE, Yates CR, Miller DD (2009) Synthesis and biological evaluation of quinic acid derivatives as anti-inflammatory agents. Bioorg Med Chem Lett 19:5458-5460

18. Hur JY, Soh Y, Kim BH, Suk K, Sohn NW, Kim HC, Kwon HC, Lee KR, Kim SY (2001) Neuroprotective and neurotrophic effects of quinic acids from aster scaber in PC12 cells. Biol Pharm Bull 24:921-924

19. Chuda Y, Ono H, Kameyama MO, Nagata T, Tsushida T (1996) Structural identification of two antioxidant quinic acid derivatives from garland (Chrysanthemum coronarium L.). J. Agric. Food Chem 44:2037-2039

20. Srinivasulu C, Ramgopal M, Ramanjaneyulu G, Anuradha CM, Kumar S (2018) Syringic acid (SA) - a review of its occurrence, biosynthesis, pharmacological and industrial importance. Biomed Pharmacother 108:547-557

21. Li Y, Zhang L, Wang X, Wu W, Qin R (2019) Effect of syringic acid on antioxidant biomarkers and associated inflammatory markers in mice model of asthma. Drug Dev Res. 80:253-261

22. Semaming Y, Pannengpetch P, Chattipakorn SC, Chattipakorn N (2015) Pharmacological properties of protocatechuic acid and its potential roles as complementary medicine. Evid Based Complement Alternat Med doi. https://doi.org/10.1155/2015/593902

23. Kakkar S, Bais S (2014) A review on protocatechuic acid and its pharmacological potential. ISRN Pharmacology, dx.doi.org/https://doi.org/10. $1155 / 2014 / 952943$

24. Wang L, Sweet DH (2012) Potential for food-drug interactions by dietary phenolic acids on human organic anion transporters 1 (SLC22A6), 3 (SLC22A8), and 4 (SLC22A11). Biochem Pharmacol. 84:1088-1095

25. Badhani B, Sharma N, Kakkar R (2015) Gallic acid: A versatile antioxidant with promising therapeutic and industrial applications. RSC Adv 5:27540-27557 
26. Tang X, Liu J, Dong W, Li P, Li L, Lin C, Zheng Y, Hou J, Li D (2013) The cardioprotective effects of citric acid and L-malic acid on myocardial ischemia/reperfusion injury. Evid Based Complement Alternat Med dx.doi. org. https://doi.org/10.1155/2013/820695

27. Ikeda I, Kobayashi M, Hamada T, Tsuda K, Goto H, Imaizumi K, Nozawa A, Sugimoto A, Kakuda T (2003) Heat-epimerized tea catechins rich in gallocatechin gallate and catechin gallate are more effective to inhibit cholesterol absorption than tea catechins rich in epigallocatechin gallate and epicatechin gallate. J. Agric. Food Chem 51:7303-7307

28. Hemshekhar M, Santhosh S, Kemparaju K, Girish KS (2012) Emerging roles of anacardic acid and its derivatives: a pharmacological overview. Basic Clin Pharmacol Toxicol 110:122-132

29. Shanmuganathan S, Angayarkanni N (2018) Chebulagic acid chebulinic acid and gallic acid, the active principles of Triphala, inhibit TNFa induced proangiogenic and pro-inflammatory activities in retinal capillary endothelial cells by inhibiting p38, ERK and NFkB phosphorylation. Vascul Pharmacol 108:23-35

30. Huang WY, Cai YZ, Zhang Y (2010) Natural phenolic compounds from medicinal herbs and dietary plants: potential use for cancer prevention. Nutr Cancer. 62:1-20

31. Fraga CG (2009) Plant phenolics and human health: biochemistry, nutrition and pharmacology. John Wiley \& Sons, Chichester:578-593

32. Estevez AM, Estévez RJ (2012) A short overview on the medicinal chemistry of (-)-shikimic acid. Mini Rev Med Chem 12:1443-1454

33. Espíndola KMM, Ferreira RG, Narvaez LEM, Rosario CRS, Silva AHM, Silva AGB, Vieira APO, Monteiro MC (2019) Chemical and pharmacological aspects of caffeic acid and its activity in hepatocarcinoma. Front. Oncol. https://doi. org/10.3389/fonc.2019.00541

34. Thirugnanasambantham P, Viswanathan S, Mythirayee C, Krishnamurty V Ramachandran S, Kameswarana L (1990) Analgesic activity of certain flavone derivatives: a structure-activity study. J. Ethnopharmacol 28:207-214

35. Rosa LS, Jordao NA, Soares NCP, Mesquita JF, Monteiro M, Teodoro AJ (2018) Pharmacokinetic, antiproliferative and apoptotic effects of phenolic acids in human colon adenocarcinoma cells using in vitro and in silico approaches. Molecules. 23. https://doi.org/10.3390/molecules23102569

36. Wang J, Fang X, Ge L, Cao F, Zhao L, Wang Z, Xiao W (2018) Antitumor, antioxidant and anti-inflammatory activities of kaempferol and its corresponding glycosides and the enzymatic preparation of kaempferol. PLOSONE. https://doi.org/10.1371/journal.pone.0197563

37. Yan X, Qi M, Li P, Zhan Y, Shao H (2017) Apigenin in cancer therapy: anticancer effects and mechanisms of action. Cell Biosci. https://doi.org/10. 1186/s13578-017-0179-x

38. Bhattacharyya SS, Paul S, Dutta S, Boujedaini N, Khuda-Bukhsh AR (2010) Anti-oncogenic potentials of a plant coumarin (7-hydroxy-6-methoxy coumarin) against 7,12-dimethylbenz [a] anthracene-induced skin papilloma in mice: the possible role of several key signal proteins. Zhong Xi Yi Jie He Xue Bao 8:645-654

39. Musa MA, Cooperwood JS, Khan MF (2008) A review of coumarin derivatives in pharmacotherapy of breast cancer. Curr Med Chem. 15:26642679

40. Pan Y, Liu D, Wei Y, Su D, Lu C, Hu Y, Zhou F (2017) Azelaic acid exerts antileukemic activity in acute myeloid leukemia Front Pharmacol. https:// doi.org/10.3389/fphar.2017.00359

41. Breathnach AS (1995) Pharmacological properties of azelaic acid. Clin. Drug Investig. https://doi.org/10.2165/00044011-199500102-00005

42. Fulda S (2009) Betulinic acid: a natural product with anticancer activity. Mol Nutr Food Res 53:140-146

43. Oak C, Khalifa AO, Isali I, Bhaskaran N, Walker E, Shukla S (2018) Diosmetin suppresses human prostate cancer cell proliferation through the induction of apoptosis and cell cycle arrest. Int J Oncol 53:835-843

\section{Publisher's Note}

Springer Nature remains neutral with regard to jurisdictional claims in published maps and institutional affiliations.

\section{Submit your manuscript to a SpringerOpen ${ }^{\circ}$ journal and benefit from:}

- Convenient online submission

- Rigorous peer review

- Open access: articles freely available online

- High visibility within the field

- Retaining the copyright to your article

Submit your next manuscript at $\boldsymbol{\nabla}$ springeropen.com 